\title{
China in Global Energy Governance: A Chinese Perspective
}

\author{
A.X. He
}

\begin{abstract}
Alex Xingqiang He - PhD, Research Fellow, Centre for International Governance Innovation; 67 Erb Street West, Waterloo, ON, Canada N2L 6C2; E-mail: hexingqiang@gmail.com

China retains a bilateral and regional cooperation approach or a geopolitical strategy to secure its energy security, while it seeks to embrace global energy governance and more actively participate in global climate change negotiations. It has also been focusing on developing clean and renewable energy since early in the 21st century. China's new Belt and Road initiative contributes to a 2.0 version of its current geopolitical strategy to secure its energy supply. Although China's emphasis on energy security still corresponds to its geopolitical strategy, its weak participation in global energy governance is due to the fragmented global energy governance system that it sees as neither authoritative nor credible, as well as to the lack of willingness or impetus for its own domestic energy institutions to join the system. Taking into account the difficulties and potential of current global energy governance, this article suggests it is reasonable to seek a limited goal for coordinating regimes instead of creating coercive institutions in this field. Attainable goals in the near future should focus on promoting a transparent international market and establishing data-sharing mechanisms between governments and energy intergovernmental organizations and between producers and consumers. There should be emphasis on climate change and clean energy governance under the United Nations Framework Convention on Climate Change. The Group of 20(G20) of should play an increasingly significant role in global energy governance. China, with its positive attitude and active participation in the G20 and as host of the G20 summit in 2016, should participate more actively, perhaps even playing a leading role in global energy governance under the G20 framework.
\end{abstract}

Key words: global energy governance, energy security concept, G20, renewable energy, climate change, Belt and Road initiative

\section{Introduction}

China began to engage and cooperate with international energy organizations in the late 1990s and early 2000s. To date, it has joined several global and regional energy-governing regimes including the International Energy Forum (IEF), the Clean Energy Ministerial and the International Renewable Energy Agency (IRENA), but remains outside several major global energy-governing regimes, including the International Energy Agency (IEA), the Organization of Petroleum Exporting Countries (OPEC) and the Energy Charter Treaty, although it has established cooperation relations with each to varying degrees.

These developments in China's participation in global energy governance, however, have received little attention both in public and from academia in China. With its increasing reliance on imported oil and gas since the 1990s, China has taken a geopolitical approach to guaranteeing its energy supply security. The official line of "active participation in international energy cooperation" in reality meant bilateral cooperation and China chose to ensure its overseas energy supply through bilateral energy cooperation, underlining the "going out" strategy and 
building overseas routes for importing oil and gas. ${ }^{1}$ This strategy was mostly implemented in Africa, the Middle East, Latin America and other places. Three land-based oil and gas pipelines were built to transport oil and gas back to China, with more built as important complements to sea routes. ${ }^{2}$ The New Silk Road Economic Belt and the Silk Road Maritime Belt, also known as the Belt and Road initiative, were finalized in 2014 and are being carried out as a grand national strategy. Energy resources constitute a significant component, given both the overlap between the Belt and Road routes and China's major oil and gas importing routes and the fact that the Silk Road Economic Belt connects Russia and some major oil and gas producers in the Middle East and Central Asia. The Belt and Road initiative is a strengthened version of China's bilateral cooperation for energy security and is being pushed strenuously.

Voices for China's more active participation in global energy governance have risen along with the country's deeper involvement in the international oil and gas market since the mid 2000s. Some scholars have argued that further participation in global energy governance could facilitate international energy cooperation and contribute to stabilizing the international energy prices, eventually benefiting China's supply security [Guan and $\mathrm{He}, 2007$; Xu, 2013; Yu, 2013]. It could also allow China to acquire the rule-making power in international energy organizations.

This article explores China's participation in international energy cooperation since it became a net oil importer in 1993. It argues that China still retains a bilateral and regional cooperation approach, while developing closer cooperation with existing major global energy-governing institutions. One argument for China's embrace of those institutions is that they support its efforts to mitigate domestic air pollution, which contribute to its goals of clean energy development and climate change control in global energy governance system. Chinese academic circles constitute the main advocates for more positive participation in global energy governance. This article suggests that the Group of 20 (G20), which provides a significant institutional arrangement for coordinating major powers' governance of international energy markets and climate change, could be the appropriate platform for China to play a more active role to its growing prominence in the $\mathrm{G} 20$.

This article begins by discussing China's traditional geopolitical approach to energy security and then examining its new concept of energy security, illustrated by China's policy evolving to embrace global energy governance and its increasingly positive policies and practices on climate change. The second part examines China's current participation in international energy organizations, highlighting the constraints facing China's participation in global energy governance. Because global energy governance is fragmented and lacks authorities, in the third and fourth parts the article observes that perhaps China should pursue limited goals focused on improving global transparency and sharing data and coordinating efforts for clean energy and climate change governance, instead of seeking comprehensive, cohesive institutions to govern global energy markets in the near future. It suggests that the G20 would be the appropriate institution to pursue such limited goals. The fifth part examines the possible advantages of China participating in global energy governance under the G20 framework, followed by a concluding section.

${ }^{1}$ It initially refers to Chinese national oil companies' pursuit of overseas oil in 1990s, which focused on purchasing foreign oil assets and equity. Intended to encourage China's enterprises to invest abroad, it was consolidated and formalized as a national grand strategy in the 10th Five-Year Plan (2001-05) in October 2000.

${ }^{2}$ The existing pipelines are Northeast (China - Russia) Pipeline, the Northwest (Central Asia) Pipeline and the Southwest (China - Myanmar) Pipeline. 


\section{Embracing Global Governance: China's New Concept of Energy Security}

\section{China's Traditional Energy Security Concept and Practices}

In general, China's concept of energy security is endowed with excessive geopolitical or geostrategic considerations. Its policy orients toward national security rather than the international energy market. China enhances its self-sufficient energy supply as much as possible by establishing more land routes for transporting overseas oil and natural gas into China and avoiding chokepoints like the Strait of Malacca. The going-out strategy was created so China could acquire more overseas energy resources. It reflects a belief that oil produced by Chinese companies abroad is a more secure source than oil purchased on international markets, so by doing so China could realize energy supply security.

Driven by insecurity in energy supply, policies to control production and transportation routes are still the first choice for Chinese elites and leaders, judging from the Belt and Road strategy and China's consistent endeavours to sign more bilateral energy supply agreements and build more land-based routes in the recent decade. The Energy Development Strategic Plan of Action (2014-20) released in November 2014 provides some perspective [Xinhua, 2014; State Council, 2014]. As far as international cooperation is concerned, the strategy focuses on the mid-term overseas energy goal to prioritize investment and trade, as well as on building and maintaining sea and land-based routes to transport energy sources back to China. It also underlines the need to expand energy import paths, especially the Belt and Road initiative, the Bangladesh-China-India-Myanmar economic corridor and the China-Pakistan economic corridor. It mentions fostering energy cooperation with five priority regions: Russia and Central Asia, the Middle East, Africa, the Americas and Asia-Pacific. It continues to encourage enterprises to implement the going-out strategy and promotes formation of regional energy markets. With regard to global energy governance, it simply mentions that China should actively participate in global energy governance [State Council, 2014]. Officials from the National Energy Administration later explained global energy governance in detail. They emphasized encouraging a free, open, orderly, competitive global energy market with effective supervision, collectively maintaining the stability of energy prices and markets, improving energy efficiency, making and perfecting the principles of global energy governance, and forging a new pattern of cooperation between consumer and producer countries [National Energy Administration, 2014]. The strategy contained no specific or meaningful proposals in this respect.

Under the strategy, China's rise as an energy-consuming and -importing power poses challenges to the existing global energy governance system in many aspects. China's tendency to secure its energy needs by signing bilateral production and supply deals undermines the principles of free trade and the generally accepted rules of investment [Goldthau and Witte, 2010]. The unique acquisition activities of Chinese national oil companies (NOCs) are characterized by bid prices that are higher than market prices and promises of large collateral social and economic investments. NOCs draw suspicion and even distrust, because they are considered closely connected to the Communist Party of China (CPC) and their investments serve China's strategic policy more than its resource policy. China's energy security strategy is seen as simply an indispensable component of a broader, grand geopolitical strategy.

Furthermore, the geopolitical energy strategy implies huge economic and political risks. It is always a reasonable and wise decision to diversify overseas energy supply. It should, however, not slide over to the other extreme: to overcome the risk of the Malacca dilemma, China chooses to establish other difficult transport routes to import oil and gas on a whatever-it-takes basis, totally ignoring the economic cost. The political strategy-oriented model of investment 
plus a worsening investment environment in the transit countries mean that the Belt and Road strategy could have huge economic risks and could make China suffer great economic losses. Accordingly, investing in energy infrastructure will not likely help improve China's energy supply security.

In practice, however, market rules matter. Chinese NOCs have followed the market rules for participating in international energy markets and do not "isolate" the equity oil they produce. ${ }^{3}$ On the contrary, they sold their equity oil in the international markets to make profit in consideration of the cost of transportation, or price differentials between global and domestic Chinese markets. In 2012, the National Energy Board announced that for the first time more than $90 \%$ of China's overseas equity production was sold locally, which contributed to the stability of the global oil market [Wang, 2012]. China's energy security in fact relies heavily on the international oil markets, not the going-out strategy and the so-called strategic oil pipelines and land-based transportation routes. China still maintains its geopolitical strategy. It is building pipelines, roads, railways and ports for acquiring access to oil and gas in energy-rich countries, guaranteed through signed bilateral cooperation agreements. The Belt and Road initiative, from the perspective of energy supply security, contributes to a " 2.0 version" of China's current geopolitical strategy to secure its energy supply.

\section{A New Concept of Energy Security}

Against the background of prevailing traditional geopolitical energy notions, a new concept of China's energy security has been growing gradually since 2006. In general, it proposes embracing global energy governance.

At the outreach session at the St. Petersburg Summit of the Group of Eight (G8) in July 2006, Chinese president Hu Jintao described a new concept of energy security [Xinhua, 2006]. He called for greater international cooperation to increase oil and gas supplies, emphasizing the need for dialogue between main energy exports and consumers. Interestingly, he stressed that efforts should be made collectively to maintain stability in oil-producing regions and ensure security in international energy routes, appealing to less politicization of energy security. He also called on research and development in energy technology.

Hu's new energy security concept was in contrast to his remark on the Malacca dilemma three years earlier. ${ }^{4}$ It was the first time a Chinese leader had emphasized international cooperation to solve energy problems. However, it was not an immediate policy change, and China still prefers not to rely so heavily on other countries to secure sea routes for importing oil and gas. Hu's proposal sounded like self-serving propaganda and lacked specific measures. Nevertheless, it still symbolized the beginning of a new energy security concept emerging in China.

In July 2011, Zeng Peiyan, chair of the China Centre for International Economic Exchange and the former vice-premier, proposed constructing a global stabilizing mechanism for energy resource markets under the G20 framework at the Energy, Resources and Sustainable Development Conference in Perth, Australia, as part of Boao Forum for Asia.

In line with the principle of mutual benefit agreed at the fifth World Future Energy Summit in Abu Dhabi, in April 2012 Chinese premier Wen Jiabao advocated establishing a mechanism for governing global energy markets comprising the largest G20 energy produc-

\footnotetext{
to retain.

${ }^{3}$ Equity oil is the proportion of production that a concession owner has the legal and contractual right

${ }^{4}$ At a central economic work conference in late 2003 , Hu Jintao reportedly expressed concern about the security of China's oil imports [Shi, 2004]. Oil imports seriously risked being cut off at the chokepoint of the Strait of Malacca, reflecting China's traditional conception of the energy security challenge.
} 
ers and consumers. Under such a framework, China hoped that fair, reasonable and binding international rules could be developed and early warning mechanisms, price coordination, financial supervision and emergency mechanisms could be built through consultation and dialogue.

This was the first specific proposal from Chinese leaders on global energy governance. It took a clear stand on building a mechanism for global energy market governance under the framework of the G20. It reflected China's willingness to participate in global economic governance, as mentioned at the Fifth Plenum of the CPC's 17th congress.

Since 2007, an increasing number of academic voices have questioned the traditional concept of energy security. Zhao Hongtu [2007] and Zhang Zhongxiang [2012] have argued that the real risks of the Strait of Malacca and other routes mainly come from pirates, terrorism and maritime accidents during peace time, not a U.S.-led oil blockade, which is highly improbable, either politically or technologically. In 2013, Zha Daojiong, an energy expert from Beijing University, and He Fan from the Institute of World Economics and Politics at the Chinese Academy of Social Sciences, once again questioned the Malacca dilemma as a fake one [Lian, 2013].

At the same time, scholars of China's traditional energy security also began to suggest that China should positively participate in global energy security cooperation and diversify its energy supply sources [Yang, 2009]. In 2013, Wu Lei [2013] called on policymakers to end the debate on whether China should participate in IEA and global energy security governance and instead "pursue such policies."

After Wen's speech in 2012, scholars from the State Council and the National Development and Reform Commission (NDRC) published research proposals on how China should participate in the global energy governance mechanism, especially under the framework of the G20. A State Council research team also published a report on "Building Global Governance Institutions on Bulk Commodity of Energy Resources," which argued that the G20's power structure and status as the premier institutional anchor in global governance create cost advantages so it could engage in the global governance of energy resource markets [Fan, Wang, Zeng et al., 2012].

In February 2014, the NDRC's Energy Research Institute [2014] and the Grantham Institute for Climate Change at Imperial College London released a joint consultation report on "Global Energy Governance Reform and China's Participation." It suggested a greater role for the G20 in providing leadership on energy governance reform, possibly through a new working group, and strengthening the G20's role as an important and representative platform for G20 leaders to discuss energy issues. It made several recommendations on how China can build capacity for participating in global energy governance and pursue more internationally minded energy policies. The report makes an effort to explain Chinese energy policies to the international community so they can be fully understood. NDRC's research team consists of retired or former high-level officials and scholars inside the system. The report further demonstrates positive movements in China's policy on global energy governance.

This transition in the concept of energy security suggests a lot for China's participation in global energy governance. The two key developments - Hu's 2006 energy security concept and Wen's 2012 proposal for a mechanism for governing global energy markets - involve China's participation in the G8 (or Group of Seven [G7]) and G20 respectively. This is no coincidence. China's closer engagement with the $\mathrm{G}-\mathrm{x}$ shows its increasingly positive attitude to engaging in global governance. 


\section{China's Efforts on Clean Energy and Climate Change}

China's increasingly positive efforts to promote clean energy and control climate change coincide with the emergence and development of its new energy concept. They also constitute aspects of China's gradual economic transition, which started around the mid 2000s. Continuous high-speed economic growth, involving large volumes of fossil fuels used inefficiently and a particularly high reliance on coal, put China under growing pressure to address environment protection and climate change both domestically and internationally. Becoming the world's biggest emitter of greenhouse gases in 2006 brought even more pressure on China. These factors pushed China to seek more flexible and pragmatic ways to deal with climate change. It showed a more positive attitude on some key issues and more enthusiasm on clean and renewable energy development, which it regarded as among the most important and promising prospects for its sustainable economic development in the 21st century [Zhang, 2007].

In its first national plan in 2007, China defined climate change as ultimately a development issue [NDRC, 2007]. Its endeavours to mitigate climate change aimed to maintain sustainable growth and solve the increasingly severe problem of pollution by reducing carbon emissions and encouraging the development of clean and renewable energy. As a result, China is rising as a clean energy superpower and has made progress on hydropower, wind power and solar power.

The Joint U.S.-China Announcement on Climate Change declared at the Asia-Pacific Economic Cooperation summit in Beijing in November 2014 issued a positive signal on climate change [White House, 2014]. It encouraged the rest of the world to take more active measures to address the issue. It augurs well for the future, and for a global deal at United Nations climate talks in Paris in 2015. China's adjustment to emphasize supporting the development of renewable energy could guarantee the realization of the goal declared in the Joint Announcement. This adoption of the so-called new normal - a new growth model that emphasizes economic upgrading and innovation - illustrates that Chinese leaders have accepted relatively slow economic growth. Environment protection and the growth of renewable energy are regarded as important for China's economic transition and improvements. China is therefore now shifting to a low-carbon economy. In doing so, it could maintain sustainable economic development while also maintaining the legitimacy of the party-state. The level of air pollution, characterized by persistent smog in most parts of the country, and growing louder chorus of pervasive complaints, are pushing Chinese leaders to prioritize environmental goals. President Xi Jinping's public response to the so-called APEC Blue at the 2014 APEC summit demonstrated that China's top leader endorses the efforts and measures for environment protection. ${ }^{5}$

\section{China's Current Participation in Global Energy Governance}

A reasonable solution to the challenges facing China's geopolitical approach on energy security is to encourage China to join the existing energy-governing bodies. It has already showed its desire and willingness to do so. At present, China is developing its relationships with almost all the relevant global and regional institutions, but it does not yet have effective or substantial cooperation with the major global institutions. It engages with the IEA, OPEC and the Energy Charter Treaty, which are each treaty-based international energy organizations. Although it has deep and substantial cooperation with regional institutions or organizations such as APEC, the

5 "APEC Blue" is a sarcastic phrase in Chinese that means something beautiful but short lived. Blue skies are ephemeral in China, especially in Beijing, because of frequent, intense smog. Before the APEC summit in Beijing in 2014, the Chinese government implemented extremely strict measures to control pollution to make sure skies were blue to impress the visiting foreign dignitaries. 
Shanghai Cooperation Organisation and the Clean Energy Ministerial, these play a minor role in global energy governance.

One constraint on China's participation in global energy governance is its emphasis on seeking supply security through its geopolitical strategy without paying equal attention to participation in global energy governance. Other constraints are flaws in current global energy governance, such as the fragmentation of the global energy governance system and a lack of implementation capacity [Lesage, 2011; Florini, 2011; Leal-Arcas and Filis, 2013; Baccini, Lenzi and Thurner, 2013]. There are also some restrictive factors, such as the securitization and politicization of states' energy policies and ensuing nationalist energy policies, which make global energy governance less authoritative and less creditable [Mares, 2010; Wilson, 2015]. China is still uncertain whether global energy governance could work effectively and to the benefit of China itself as well as other countries. Yet another constraint is the possibility that domestic oil and gas interest groups would contain China's participation in the global energy governance, which requires more transparency in its own domestic energy governance. This would put China's oil and gas interest groups in a more difficult position to benefit themselves.

\section{Seeking Limited Goals for Global Energy Governance}

A fragmentized, less authoritative and less creditable system would demonstrate the great difficulties facing global energy governance. However, market forces and rules matter in the field of international oil and gas, and they provide the basis for global energy governance. Geopolitical and mercantilist frameworks cannot alone explain the fluctuation of global oil markets [Goldthau and Witte, 2010]. Besides, states have demands for effective global energy governance. The information that intergovernmental organizations can provide is usually detailed and highly valuable in the energy market, which is the first reason why states join them [Harks, 2010]. Most countries need redundant and continuous supply networks to guarantee their energy security and reduce costs [Nicolas, 2009]. This reveals the inherent basis and potential of the global energy governance system. In light of both difficulties and possibilities, perhaps it would be reasonable to seek a limited goal for coordinating energy-governing regimes instead of coercive institutions.

First, the big picture of a limited goal is that it is attainable. It should not be a coercive, universally accepted international institution that provides collective energy security to all states in the world, but an international regime to coordinate policy among governments effectively, guarantee a stable energy supply, provide access to energy - especially oil and natural gas - and ensure environmental sustainability. In general, the coordination should include the basic elements of energy governance: measures to correct market failures, to lower transaction costs by promoting transparency and information sharing, to deal with external shocks, to set rules and standards for market exchange, and to promote new multinational infrastructure investment to foster interconnection and security. Specifically, the key question is how to coordinate energy policies made by independent national governments, i.e., interaction between global and national energy-governing bodies, and how to coordinate among the relevant major institutions, for example the IEA, IEF, OPEC, G7 and G20.

In reality, effective coordination still remains difficult in most cases. Although effective coordination among different dimensions and institutions should be the final goal, in the near future the basic and achievable goals should be the promotion of a transparent international market and data-sharing mechanisms between governments and energy intergovernmental organizations and between producers and consumers. The purpose of the coordination mechanism is to reduce uncertainty and lower transaction costs in international energy markets. In terms of enforcement, global energy governance should be built on soft law rules, including 
political consensus among state leaders, voluntary commitments, peer pressure and incentivebased implementation.

Second, there should be an emphasis on climate change and clean energy governance. The demand for good governance on climate change, environment protection and renewable energy will provide steady momentum for global energy governance, although it will also bring more complexities. Climate change concerns both producers and consumers and has already developed into a fundamental issue in global energy governance. Less securitization and relatively weaker economic nationalism in the field of climate change and environment protection mitigates the negative influences brought about by the re-emergence of state players in the global governance of climate change.

Unlike the fragmented global governance of oil and gas markets, there is a treaty-based, universal governance regime in climate change governance. The United Nations Framework Convention on Climate Change (UNFCCC), with 196 parties, has near universal membership. Its Kyoto Protocol has been ratified by 192 parties. ${ }^{6}$ The UNFCCC promotes the global governance of climate change through negotiations and progress has been made since the Kyoto Protocol. The key question that remains is what kinds of international institutions in global governance are needed to implement the goals and frameworks that have been agreed to. In other words, ways to promote the implementation of the low-carbon policies and technologies need to be found. Although some failures happened, including the refusal of Russia, Japan, Canada and New Zealand to commit to the second phase of the Kyoto Protocol at the Doha climate conference in November 2012, the UNFCCC remains the provider of rules on climate change through negotiations. What is more, the joint U.S.-China announcement on climate change in November 2014 offered an incentive for further implementing goals to reduce carbon emissions.

Renewable and clean energy could contribute greatly to the mitigation of climate change and could even be a last-resort solution in the future. It is also a promising industry that could be a driving force for reviving and developing an economy. As far as the global governance of renewable energy is concerned, the main focus should be on promoting development and sharing, and the transfer of clean, renewable and new energy technologies, based on intellectual property protection. Some existing arrangements can be used in this regard: the negotiations on the Environment Goods Agreement at the World Trade Organization, launched in July 2014, could be expanded to include the transfer of clean and renewable energy technologies. In that case, the new energy technologies could be used to promote both energy security and the mitigation of climate change.

\section{The G20 and the Limited Goals for Global Energy Governance}

The rise of the G20 in global economic governance since the 2008 global financial crisis provides another option for global energy governance. As a global high-end forum and a bridge among big powers, the $\mathrm{G} 20$ is often considered an appropriate platform for coordinating action among leading states [Dubash and Florini, 2011]. It is currently the most plausible forum where broad directions for global energy governance could be decided, making it an important arena to watch for the future [Dubash and Florini, 2011]. Three characteristics explain the virtues for the G20 to play an increasing significant role in global energy governance.

First, the G20 provides key political consensus and willingness by issuing public declarations. Its members include the most significant developed and developing economies, accounting for $85 \%$ of global gross domestic product.

${ }^{6}$ See “About UNFCCC" at http://newsroom.unfccc.int/about. 
Second, flexible institutional arrangements could be another advantage for establishing effective global energy governance under the framework of the G20. Such arrangements involving the International Monetary Fund (IMF), World Bank and the G20 proved to be an effective model for handling the global financial crisis, which provides a possible road map for future institutional cooperation in global energy governance. The institutional cooperation or association between existing main organizations involved in global energy governance, such as the IEA, the IEF and the G20, could be a possible shortcut for a future model. Following the existing successful cooperation model between the IEA and the G7, together with the fact that the G7 has given way to the G20, the IEA may continue to play a rather unusual direct role of responding to "assigned tasks" by the G20 [Florini, 2011].

Third, G20 members include the most important players in international energy market: the leading energy producers of Saudi Arabia and Russia and the biggest energy consuming powers of China, India and the United States, as well as other G7 members, most of them also big consumers.

The rise of the G20 as a primary forum for global economic governance laid a good foundation for it to play a more significant role in global energy governance. Cooperation between the G20 and major global energy-governing bodies has developed over time. The IEA has played a supporting role since the Pittsburgh Summit in 2009. Since 2011, cooperation to tackle price volatility in international markets for oil, gas and coal has been a priority. Together with the IEF and OPEC, the IEA reported to the G20 on volatility in oil markets in July 2011 and on gas and coal volatility in October 2011. In July 2014, the JODI-Gas World Database was officially launched.

The G20 has the potential to provide leadership at the highest level on energy policy as on other matters [Hirst and Froggatt, 2012]. Dries Lesage [2011] believes the G20 can take the lead in developing a modern and coherent strategy for a sustainable energy future that benefits everybody, expressing optimism on the role that can be played by the G20 in global energy governance. There are two noteworthy performances by the G20 in global energy governance. First, it has undertaken efforts to curb excessive volatility in oil prices and enhance transparency in oil and gas markets. A key element in this exercise is the improvement of the JODI database. Another important project is the phase-out of fossil fuel subsidies, which now contribute massively to global warming and cost the governments of developing countries' billions of dollars per year [Lesage, 2011].

However, not much progress has been made since 2011. At present, the transparent oil and natural market information system, represented by the JODI database, is supported by relevant countries through the G20 platform. Clearly, political support from G20 members is vital to enhance the reliability and relevance of JODI and its further success. In addition, financial support for JODI seminars from G20 members is important for further development of the initiative. This constitutes a significant part of JODI's capacity building. In short, a comprehensive (including oil, gas and coal) and authoritative JODI data-sharing mechanism is fundamental for effective global energy governance. It should be a real goal of global energy governance and attainable in the near future.

The goal to phase out inefficient fossil fuel subsidies was agreed to at the 2009 Pittsburgh Summit. Progress since then, however, has been slow. There was no strict timeline or road map set out, although almost every summit since then has called for the elimination of these subsidies. The slow progress has been used as proof of the failure of the G20 and to oppose involving the G20 in global energy governance. At the 2012 Los Cabos Summit, G20 leaders tasked their finance ministers with establishing a voluntary peer review process for G20 members. The process is mostly undertaken through a process of mutual review between countries, but 
this is subject to difficulties among members of G20 and often takes time. The United States and China, the two biggest powers with large numbers of fossil fuel subsidies, agreed to do a joint peer review of those subsidies in the 2014 U.S.-China Joint Announcement on Climate Change, which should have boosted the slow process. Once the first round of voluntary peer review by the United States and China was complete, a second round involving other G20 members was expected to commence in mid 2015 [G20 Energy Sustainability Working Group, 2014]. By October 2015, the reviews by the United States and China were being finalized and Germany and Mexico had announced they would undergo a second round of peer reviews [IEA and OECD, 2015].

The Clean Energy Ministerial, a multilateral U.S. initiative that resulted from the Copenhagen climate conference in 2009, is another G20-related achievement on global energy governance. It began to report to the Cannes Summit in 2011. The G20 Leaders' Declaration at St. Petersburg in 2013 echoed the call by the International Atomic Energy Agency Action Plan on Nuclear Safety for multilateral cooperation to achieve a global nuclear liability regime, one year after the Fukushima catastrophe in 2011.

The ongoing energy initiatives and close engagement of the G20 regimes are very significant for addressing the real weaknesses and gaps in global energy governance, although progress, including creating a JODI mechanism and phasing out fossil-fuel subsidies, is very slow. One main reason for the slow progress concerns the very nature of the G20, which does not act as a genuine political steering committee in the fragmented field of global energy governance. As stated earlier, energy is an issue highly burdened with strategic implications. Governments are reluctant to engage closely with any official multilateral institution equipped with cohesive mechanisms for more coordination. An informal country grouping with a voluntary process, however, might be easily accepted. To make it worse, energy issues are still not among the top priorities on the G20's agenda, so there is less political will to push for the goals of the energy governance.

Lesage [2011] suggests establishing a G20 energy task force to do the overall strategic thinking on global energy governance that would contribute to policy coherence and provide the political stimulus on behalf of the countries that bear a great responsibility for the world's energy problems. Other scholars have proposed a standing, but flexible, network of officials from the G20 and multilateral institutions, comparable to the Financial Stability Board [Victor and Yueh, 2010]. However, constraints on the G20 prevent these proposals from being considered seriously. New momentum for global energy governance is needed, and perhaps China's more active engagement can deliver the necessary thrust.

\section{China's Participation in Global Governance through the G20}

China could reap huge advantages by actively participating in global governance by way of the G20 at a low economic and political cost. By participating in the G20 summits, China entered onto the centre stage of global economic governance and has received recognition and approval as a major economic power in the G20. It has recently demonstrated an understanding of the significance of the G20, particularly as a platform for promoting effective governance of global energy markets.

Most importantly, the G20 provides an alternative to guarantee China's energy security. The rise of the G20 and global governance achievements in economics, finance, development and energy demonstrates that the new concept of collective security to guarantee energy security provides another choice for China's efforts to secure its own energy supply. It has almost no cost economically and zero risk politically, compared to its geopolitical strategy. All that is needed from China is to change the concept for its elites and top policymakers and to involve 
talents and bureaucratic agencies more. The potential gains could be greater than those from a geopolitical approach.

Second, participation in global energy governance under the G20 is a good choice to appease the doubt from western countries about China's motivation for acquiring global energy and to enhance China's image, improving relations with western countries in the international energy market. With its huge volume of imported oil and gas in the international market and its outsider status with regard to major international energy organizations, China constitutes the weakest link in the existing global governance of energy markets and also the most challenging factor. Its closer engagement and initiatives in energy governance under the G20 framework will be a convincing sign to other major players that China could be a constructive force in global energy governance.

Third, China should take the opportunity of its 2016 G20 presidency, when it can put energy governance on the list of top priorities, to negotiate a way to join the IEA. Among all the organizations engaged in global energy governance, the IEA has the greatest potential to be "the one" in the future. Ann Florini [2011] believes that despite its constrained membership, the IEA is at the centre of many key developments in global energy governance. As a non-member partner country, China already cooperates with the IEA in many aspects. China's Ministry of Science and Technology and the IEA have established good communication channels for policy research. China has a cooperation agreement with the IEA's network of 40 international technology cooperation agreements. Since 2013, China has belonged to 19 of its implementing agreements for technology collaboration and regularly participates in its senior technology committee. The IEA has expressed an interest in China joining the organization. ${ }^{7}$ If China is determined to join, the requirement of being a member of the Organisation for Economic Cooperation and Development (OECD) should not be a major stumbling block. From China's point of view, joining IEA would represent a significant shift in its energy security strategy and would imply that China embraces the liberal way to seek its energy supply security. It requires great determination to move forward.

Fourth, substantial participation in global energy governance can help China acquire the capability for engaging in setting prices on international oil and gas markets. Several means are available to improve China's performance: coordinating strategic oil reserves; joining the major energy governance mechanisms; and updating the Shanghai International Energy Trade Centre and making it the "Shanghai crude oil future trading centre" to participate in international oil trade. Some progress has been made in this regard. The China Securities Regulatory Commission approved the trade of crude oil futures on the Shanghai Futures Exchange in December 2014. All these goals can be facilitated if China pursues them under the framework of the G20. At the 2014 G20 Brisbane Summit, China agreed to publish data on its oil reserves, and it has already reached an agreement with the United States on a joint peer review of inefficient fossil fuel subsidies under the G20. These are important steps for China's participation in energy governance at the G20. Its future involvement in the comprehensive JODI oil information mechanism through the G20 will be helpful for building the Shanghai crude oil future trading centre based on transparency and effective supervision.

Fifth, innovation in energy technology, especially clean energy, is significant for countries such as China and the United States to achieve their goals in clean energy and climate change. Cooperation and transfer in energy technology, especially clean energy, are highly important for promoting common goals in climate change. The G20 is the perfect platform to promote cooperation in energy technology. The Clean Energy Ministerial, the International Renewable Energy

${ }^{7}$ Nobuo Tanaka, as IEA president, once said that if China demonstrated a strong desire to join, the IEA could modify its membership rules that prevented it from joining [Wang and Wei, 2013]. 
Agency (IRENA) and the International Partnership for Energy Efficiency Cooperation (IPEEC) are institutions focused on developing clean, renewable energy and energy efficiency, and they have close working relations with the G20 under the G20 Energy Efficiency Action Plan. ${ }^{8}$

G20 summitry is widely perceived in China's policy communities as the ideal platform for participating in global governance. To create and strengthen a political framework for international energy cooperation, China needs to play a leading role in the G20. The facts that energy governance is not the top priority on the G20 agenda and that China is not a member of major international energy organizations restrain China's active engagement on energy governance at the G20. However, with the United States unwilling and incapable of action due to domestic deadlock and with China's hosting the summit in 2016, China is expected to lead the G20 with its agenda-setting responsibilities and its energy goals could be pushed.

\section{Conclusion}

China currently prioritizes a traditional geopolitical approach over participation in global energy governance for its energy supply security. The new Belt and Road strategy, although still mainly focused on regional and bilateral ways to promote China's energy security, contains elements that could lead to China's more active participation, including in global governance. The key question is whether such active participation in global governance can coordinate with China's geopolitical approach. The litmus test will be how China promotes the Asian Infrastructure Investment Bank and what kind of rules and governing mechanisms of the bank are established. How will it address its role in advancing the infrastructure investment and construction in Asia, including energy infrastructure, to accommodate China's interest in connecting the neighbouring countries and energy-rich Central Asia and the Middle East? What can China do with its hosting of the G20 in 2016 with respect to global energy governance?

The biggest advantage of the G20 platform is that it brings together the strengths and resources of existing international regimes to push its own agenda. Just as the G20 has worked closely with the IMF and the World Bank, China should push the G20 energy working group to establish a closer connection with the IEA and OPEC to begin discussions on setting up a framework for global governance of energy markets. Chinese leaders understand that the G20 is one of a few international institutions in which China is an equal participant, and even as a leading country. The energy-governing issues handled at the G20 through its energy arrangements could maximize China's interest in participating in global energy governance, despite not being a member of the IEA, OPEC, the Energy Charter Treaty or other important global energy-governing organizations.

The G20 Hangzhou Summit is a golden opportunity for China to play a positive, even a leading, role in global energy governance. As a leading consumer of energy and renewable energy, China should put the issue of global energy governance on its list of priorities for the G20 agenda. Given China's lesser engagement with existing global energy-governing organizations and its marginalized status in the global energy governance system, new channels would be China's best choice. China should put clean energy and climate change control as the most important issues for its participation in global energy governance at the G20. Meanwhile, as the

\footnotetext{
${ }^{8}$ In 2015, IPEEC reported to the G20 through the Energy Sustainability Working Group. The Global Superior Energy Performance Partnership (GSEP) is one of the CEM's 13 initiatives. The GSEP Power Working Group also reported to the G20 in 2015 through the G20 Energy Sustainability Working Group on sharing knowledge of high-efficiency, low-emissions electricity-generation technologies. At IRENA's 2015 assembly, Turkey - which held the presidency of the G20 in 2015 and is also a member of IRENA - declared it would leverage synergies between the G20 and IRENA, with a focus on promoting energy access in subSaharan Africa and assessing the influence of falling oil prices on renewable energy investments [International Institute for Sustainable Development, 2015].
} 
largest oil importer, China cannot afford to be excluded from the energy cooperation on fossil fuels. A specific and substantial, but not extremely complicated, issue can be an appropriate starting point for China's involvement. Information sharing through the JODI database, operated by the IEF, the IEA and OPEC on the G20 platform, is perhaps one option.

\section{References}

Baccini, Leonardo, Veronica Lenzi and Paul W. Thurner (2013) "Global Energy Governance: Trade, Infrastructure and the Diffusion of International Organizations.” International Interactions 39(2), pp. 192-216. doi: 10.1080/03050629.2013.768512.

Dubash, Navroz K. and Ann Florini (2011) “Mapping Global Energy Governance.” Global Policy 2, pp. 6-18. doi: 10.1111/j.1758-5899.2011.00119.x.

Energy Research Institute and Grantham Institute, Imperial College London (2014). "Global Energy Governance Reform and China's Participation: Consultation Report.” November. London. http://www. imperial.ac.uk/grantham/publications/collaborative-publications/global-energy-governance-reform-andchinas-participation.php (March 2016).

Fan, B., J. Wang, S. Zeng et al. (2012) “Goujian dazong nengyuan ziyuan quanqiu zhili jizhi.” Caijing Magazine, 31 March.

Florini, Ann (2011) “The International Energy Agency in Global Energy Governance." Global Policy 2, pp. 40-50. doi: 10.1111/j.1758-5899.2011.00120.x.

G20 Energy Sustainability Working Group (2014) “G20 Energy Sustainability Working Group 2014 Co-chairs' Report.” G20, Melbourne, 10 November. http://www.g20australia.org/sites/default/files/g20_resources/ library/g20_energy_sustainability_working_group_2014_co-chairs_report.pdf (March 2016).

Goldthau, Andreas and Jan Martin Witte (2010) "The Role of Rules and Institutions in Global Energy: An Introduction.” In: Andreas Goldthau and Jan Martin Witte, eds., Global Energy Governance: The New Rules of the Game. Washington DC: Brookings Institution Press. pp. 1-21.

Guan, Q. and F. He (2007) "Zhongguo de nengyuan anquan yu guoji nengyuan hezuo." ["China's Energy Security and International Energy Cooperation."] Shijie Jingji yu Zhengzhi [World Economics and Politics] (11).

Harks, Enno (2010) "The International Energy Forum and the Mitigation of Oil Market Risks." In: Andreas Goldthau and Jan Martin Witte, eds., Global Energy Governance: The New Rules of the Game. Washington DC: Brookings Institution Press. pp. 247-67.

Hirst, Neil and Anthony Froggatt (2012) "The Reform of Global Energy Governance." Grantham Discussion Paper, 1 December. London: Chatham House. https://www.chathamhouse.org/publications/papers/ view/188185 (March 2016).

International Energy Agency and Organisation for Economic Co-operation and Development (2015) "Update on Recent Progress in Reform of Inefficient Fossil Fuel Subsidies That Encourage Wasteful Consumption." Submitted to the G20 energy ministers' meeting, 2 October. http://www.g20.utoronto.ca/2015/Update-onRecent-Progress-in-Reform-of-IFFS-that-Encourage-Wasteful-Consumption.pdf (March 2016).

International Institute for Sustainable Development (2015) "Summary of the Fifth Assembly of the International Renewable Energy Agency." Earth Negotiations Bulletin 30(8). http://www.iisd.ca/vol30/enb3008e.html (March 2016).

Leal-Arcas, Rafael and Andrew Filis (2013) "The Fragmented Governance of the Global Energy Economy: A Legal-Institutional Analysis." Journal of World Energy Law and Business 6(4), pp. 1-58. http://papers.ssrn. com/sol3/papers.cfm?abstract_id=2296311 (March 2016).

Lesage, Dries (2011) “The Time Has Come for a G20 Energy Task Force.” In: John J. Kirton and Madeline Koch, eds., The G20 Cannes Summit 2011: A New Way Forward. London: Newsdesk Media. pp. 223-25. http:// www.g8.utoronto.ca/newsdesk/g20cannes2011.pdf (March 2016).

Lian, W. (2013) "G20 kuangjia xia woguo de guoji jingji zhanlue.” ["China’s International Economic Strategy under the G20 Framework.”] 21 Shiji Jingji Baodao [21st Century Business Herald], 21 August. 
Mares, David R. (2010) "Resource Nationalism and Energy Security in Latin America: Implications for Global Oil Supplies.” January. Houston: James A. Baker III Institute for Public Policy. https://bakerinstitute.org/ media/files/Research/edacf0ea/EF-pub-MaresResourceNationalismWorkPaper-012010.pdf (March 2016).

National Development and Reform Commission (2007) "China's National Climate Change Programme." People's Republic of China, Beijing, June. http://www.ccchina.gov.cn/WebSite/CCChina/UpFile/File188. pdf (March 2016).

National Energy Administration (2014) "Guojia nengyuanju youguan fuze ren jiu 'nengyuan fazhan zhanlue xingdong jihua (2014-2020 nian)' da jizhe wen.” ["Leaders from the National Energy Administration Answer Reporters' Questions on the Energy Development Strategic Plan of Action (2014-20).”] Beijing, 15 December. http://www.nea.gov.cn/2014-12/15/c_133855760.htm (March 2016).

Nicolas, François (2009) “ASEAN Energy Cooperation: An Increasingly Daunting Challenge.” September. Paris: Institut Français des Relations Internationales. http://www.ifri.org/en/publications/enotes/notes-delifri/asean-energy-cooperation-increasingly-daunting-challenge (March 2016).

Shi, Hongtao (2004) "Zhongguo nengyuan anquan de qianzai weixie: guodu yilai malacca haixia." ["A Potential Threat to China's Energy Security: Overdependence on the Straits of Malacca."] Zongguo Qingnian Bao [China Youth Daily], June. http://news.xinhuanet.com/world/2004-06/15/content_1526222.htm (March 2016).

State Council of the People's Republic of China (2014) "Nengyuan fazhan zhanlue xingdong jihua (20142020 nian).” [“Energy Development Strategy Action Plan (2014-2020).”] November. Beijing. http://news. xinhuanet.com/2014-11/19/c_1113313588.htm (March 2016).

Victor, David G. and Linda Yueh (2010) "The New Energy Order: Managing Insecurities in the Twenty-First Century.” Foreign Affairs 89(1), pp. 61-73. https://www.foreignaffairs.com/articles/2009-12-21/new-energyorder (March 2016).

Wang, E. and W. Wei (2013) "IEA xuyao zhongguo, zhongguo ye xuyao IEA.” ["The IEA Needs China and China Needs the IEA.”] Zhiji Jingji Baodao [21st Century Business Herald], 9 July.

Wang, X. (2012) "Guojia Nengyuanju: Zhongguo Haiwai Quanyiyou 90\% Yishang Dangdian Xiaoshou." ["National Energy Board: More Than 90\% of Chinese Overseas Equity Oil Sold Locally."] Caixin.com. http:// companies.caixin.com/2012-12-03/100468168.html (March 2016).

White House (2014) "U.S.-China Joint Announcement on Climate Change." Beijing, 12 November. https://www. whitehouse.gov/the-press-office/2014/11/11/us-china-joint-announcement-climate-change (March 2016).

Wilson, Jeffrey D. (2015) "Multilateral Organisations and the Limits to International Energy Cooperation." New Political Economy 20(1), pp. 85-106. doi: 10.1080/13563467.2013.872611.

Wu, Lei (2013) "Zhongguo nengyuan anquan mianlin de zhanlue xingshi yu duice." ["China Energy Security: Strategic Environment and Policy Options."] Guoji anquan yanjiu [Journal of International Security Studies] (5).

Xinhua (2006). "Hu jintao chanshu quanqiu nengnuan anquan.” ["Hu Jintao Expounds Global Energy Security.”] 18 July. http://news.xinhuanet.com/politics/2006-07/18/content_4847040.htm (March 2016).

Xinhua (2014). "China Unveils Energy Strategy, Targets for 2020.” Beijing, 19 November. http://news. xinhuanet.com/english/china/2014-11/19/c_133801014.htm (March 2016).

$\mathrm{Xu}, \mathrm{B}$. (2013). "Shichang shiling, jizhisheji yu quanqiu zhili." ["Market Failure, Institution Design and Global Energy Governance.”] Shijie Jingji yu Zhengzhi [World Economics and Politics] (11).

Yang, Z. (2009). "Zhongguo nengyuan anquan xianzhuang ji zhanlue xuanze.” ["China's Energy Security: Status Quo and Strategies."] Renmin luntang [People's Forum] (276).

Yu, H. (2013). "Nengyuan zhili de gongli zhuyi he quanqiu zhuyi." Guoji anquan yanjiu [Journal of International Security Studies] (5). Globalism and Utilitarianism in Global Energy Governance.

Zhang, Haibin (2007). "Zhongguo yu guoji qihou bianhua tanpan." ["China and International Climate Negotiations."] Guoji zhengzhi yanjiu [International Politics Studies] (1), p. 16.

Zhang, ZhongXiang (2012). "Why Are the Stakes So High?" In: Huw McKay and Ligang Song, eds., Rebalancing and Sustaining Growth in China. Canberra: ANU E Press. pp. 329-56.

Zhao, Hongtu (2007). "Malacca kunju yu zhongguo nengyuan anquan zai sikao.” ["Malacca Dilemma: Rethinking China’s Energy Security.”] Xiandai guojiguanxi [Contemporary International Relations] (6). 